\title{
A Descriptive Enquiry for Indentifying Factors Affecting Generation $X$ and Generation $Y$ at the Workplace
}

\author{
Ms. Rima Gupta \\ (Assistant Professor, St. Kabir Institute of Professional Studies, Ahmedabad, Gujarat) \\ Dr. Rupali Singh \\ (Human Resource Head, Balaji Flex)
}

\begin{abstract}
:
The unprecedented growth of various generations working side by side has prompted the human resource management practitioners and the academicians to recognize the existence of intergenerational differences among workers. This paper attempts to identify and examine the characteristics of Generation $\mathrm{X}$ and Generation $\mathrm{Y}$ and the factors that affect the working relationship of these two generations. We find the similarities and differences in the characteristics, work attitudes, and work variables that need to be addressed so that both the generations can work effectively and the productivity of both the generations can be leveraged. A set of factors are also identified which affects both these generations.
\end{abstract}

Keywords : Generation X; Generation Y; generational differences; factors affecting generational differences; generational cohorts.

\section{Introduction :}

Human capital is the collective value of the capabilities, knowledge, skills, life experiences, and motivation of the workforce. (Aldisent,2002). According to an article in Forbes Magazine, 2017, and according to a CFO Research Services report, 2018, nearly all CFOs worldover recognize the power that human capital exercises in key business areas like customer satisfaction, product/service innovation, growth, and overall profitability.

According to World Economic Forum's Annual Meeting 2017, rapid technological advances and the digitization of the workplace are making it difficult for employees to match their skill sets 
with the needs of companies and so the problem of human capital management (HCM) as defined by Forbes, and skill-shortage has arisen. As per a Talent crunch survey conducted by Korn Ferry Board and CEO Services in 2018, skilled talent shortages will continue to retard global growth and can have a significant impact on major economies by 2030 .

According to research by Manpower group Survey, 2018 presented in Figure 1, Global Talent Shortage is reported at $45 \%$ which is at a 12 year high compared to $40 \%$ in 2016-17. Though the gravity of that problem varies between countries, according to the Organization for Economic Cooperation and Development (OECD) and the Manpower Talent Shortage Survey,the problem of skill shortage is found to be most profound in Asia with India ranking second globally with $64 \%$, after Japan at $81 \%$.

Figure 1: The countries facing the greatest skill shortages:

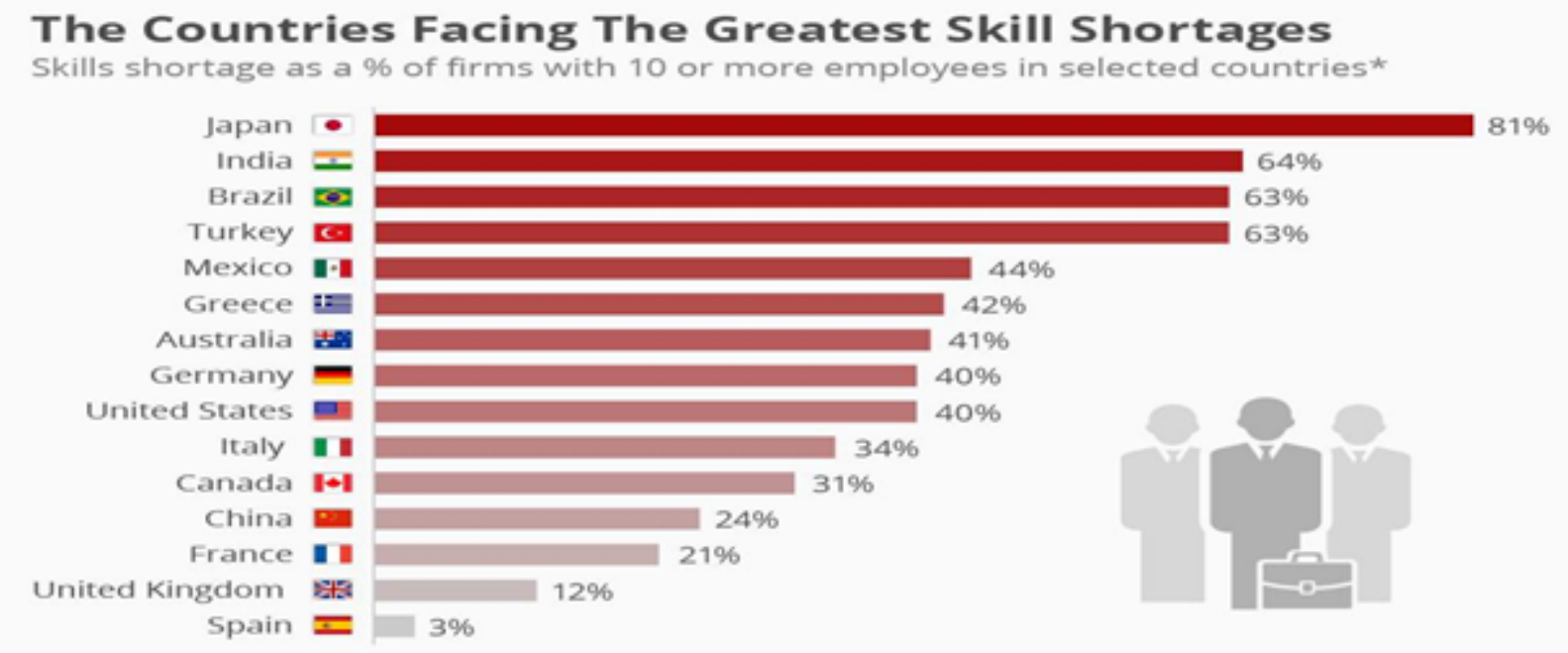

Source: Manpower Talent Shortage Survey via OECD

Korn Ferry's Global Talent Crunch study estimates the gap between future talent supply and demand in 20 major economies at three milestones: 2020, 2025 and 2030.

The IBR data, 2017 finds that globally, $+36 \%$ of businesses expect to hire more staff overtime.However, compared to 2016, a skilled worker shortage will hamper growth have increased by 2 percentage points in Asia Pacific, 2pp in North America and 5pp in the EU.

As an attempt to address this global skill shortage and build upon the relevant talent pool, employers globally have started to rethink new approaches to acquire and build the relevant talent. According to Manpower Group Survey, 2018, to win in this digital age and keep pace 
with today's Skills Revolution, an effective talent strategy should comprise four key elements: Build, Buy, Borrow, Bridge.

Seconding the above solutions, articles in Wall Street Journal, By Peter Cappelli(2011) and a research survey by HCM, suggest that the organizations worldwide can resort to a few ways mentioned below, to address these shortages, simultaneously keeping their daily operations smooth:

\section{Train Existing Employees:}

To handle the skills shortage, many companies train their existing employees, to shape them to fill current gaps. This can begin in-house training, where a knowledgeable employee trains junior employees. It's a great way for companies with good resources to increase their value without spending much time on money and time.

Another alternative is seeking outside training. Several businesses offer their employees incentives to employees to get additional degrees. While this option can be more expensive, it also has larger benefits in the long run. It ensures thatemployees are trained to industry standard quality, also, it can attract talented workers to the company.

\section{Adaptability - Apply Workforce Skills In A Different Way:}

Interestingly, many companies have discovered that they already have talented employees, but are merely ineffectively using them. It's important to gauge your available skill sets, paying close attention to skills that could be transferable.

Consider employees that might be able to apply their skills differently - someone with a strong sales background could easily apply their abilities to marketing content for example. Someone with a strong background in communications could find an excellent new career in sales, someone with engineering skills and a background in the automotive industry could easily find themselves in a comfortable career as a resource manager, and so on. The key to solving your skills shortage might be within the organization.

\section{Re-evaluate Your Recruiting Practices:}

When skills shortages become such a serious concern, it might be time to re-evaluate the recruitment employees. Without hurting your company, one could easily hire applicants with $80 \%$ of the right requirements and help them grow into the role. Or, hiring applicants with all the right skills, but ones with less experience than initially wanted who can be trained later.

If diversify is practiced in hiring, and considering transferable skills, one could find excellent, motivated individuals who could easily help your company reach its goals. 


\section{Partner with Nearby Educational Facilities:}

Though rarer in recent times, many organizations would partner with local educational institutes - to have a fresh supply of skilled potential workers as the school would be able to help graduates in placements. Companies are also open to apprenticeships, co-op work placements, and internships, which can help nurture the next generation of skilled workers. Best of all, keeping a close eye on the future of the respective industry is possible.

\section{Use Contingent Workers:}

Contingent workers are becoming an incredibly popular option for many, considering their expertise, availability, and flexibility, which allows them to work within the confines of any time or cost. Many companies feel as though any labor risks involved is outweighed by their sheer benefits. With freelancers, consultants, contractors, and more, you can fill massive gaps in your operation quickly and in a cost-effective manner. Unlike a lot of areas of the labor market, contingent workers are on an ever-growing trend which means there are enough to meet your needs for as long as you need.According to Randstad, approximately half (46 percent) of workers surveyed said they chose to become a contingent worker. The same ways have been backed and suggested by many by AON Hewitt, The globe and Mail magazine and Spark magazine.Naturally, one of the easiest ways to fill a skills shortage is by hiring contingent workers.

\section{Promote from within:}

As all the above-mentioned approaches, in turn, would have employees of various age groups or generations coming together and contributing to achieving the organizational goals in various capacities, it will thus be making imperative for the organizations and practitioners to address and manage the intergenerational diversity that would be seen in the workforce.It helps build the supply of human capital in the economy, as well as opening the pathway for more people to get jobs.

To implement all the approaches effective, the organizations would need to manage all aspects of diversity like age, ability, ethnicity, and sociality. Of course, it's also much better for society. Contrastingly, by using on-the-job education strategy employees can be given projects that help them learn new skills, thus expanding the supply of talent that employers can tap, making it both cheaper and easier to fill jobs. According to data from Taleo Corp., a talent-management company, in recent years an incredible two-thirds of all vacancies, even in large companies, have been filled by hiring from the outside. 


\section{Need of the hour: Addressing Generational Differences :}

The principal reason has been a lack of research to validate the significance of these differences (Arsenault.P.,2004). There is a need, therefore, for more research on leveraging generational diversity for organizations to run as smoothly and efficiently as possible, it is imperative to address generational diversity in the workplace from a preventative measure rather than reactionary.

While research on Gen $\mathrm{X}$ is slightly more developed given their slightly longer tenure in the workplace, much of what is written about them is still subjective. Given that younger workers are often employed on a part-time basis, this dearth of research on younger workers is not surprising because of a tendency illustrated in the literature to study full-time workers (Louglin\&Barling, 2001). We especially lack studies examining the implications of generational differences in the design of jobs (e.g. The importance of context for understanding behavior of people in different generations should be addressed, a subject often missing from the discussion of generational similarities and differences. Much of the existing literature employs nonempirical sources such as anecdotal accounts or extrapolations based on different generations' life experience; at best, this literature relies on qualitative interviews (e.g., Chester, 2002; Lancaster \& Stillman,2003; Tulgan, 2003, and, 2009; Zemke et al, 1999).In addition, most past research on generational differences has focused on comparing Boomers and GenX (Beutell\& WittigBerman, 2008; Davis et al., 2006; Smola\& Sutton, 2002). Defined as a shared tradition and culture by a group of people that is lifelong, differences in generations have been plagued by erroneous misconceptions. Smola and Sutton,2002; Giancola, 2006; Lawler, 2011), while empirical findings related to generational differences are still rare and non-conclusive (e.g. (Patalano, 2008).

While much research has been done on motivation and generational attributes, little has been done to identify the work values of each generation and to show how these work values can cause conflict in the workplace.(Rochelle R., Croweder B., 2017). Empirical evidence for generational differences in work values is scant. Today's workforce is more diverse than ever. One diversity issue that has not been generally recognized is generational differences.

The relatively sparse empirical research published on Millenials is confusing at best and contradictory at worst. Although we know that work design does not have universal effects on different employees, many workplaces are still not well-designed to meet the altered capabilities and preferences of a generationally diverse workforce (e.g. As per a research paper, "Leveraging Generational diversity at Workplace" by Julie Cogin, published in International Journal of Human Resource Management, 2011, while cultural and gender diversity has received significant attention in the literature, little attention has been paid to the impact of age diversity 
on HRM practices. Sturman, 2003; de Lange et al., 2010; Truxillo et al., 2012). Generation Y (GenMe), the youngest and fastest-growing generation in today's workforce has received little if any, empirical examination.

Giancola (2006) for example observes a lack of published research on generational differences in academic journals and suggests that "the generational approach may be more popular culture than social science" (p. Additionally, there are only a handful of empirical studies that focus on generation group identity as it relates to organizational commitment. There is a need for employers to know how their Gen X and Gen Y employees' attitudes about organizational commitment differ to help them manage turnover, absenteeism, and job performance. (Jennifer et al., 2010)

In recent years, there has been, particularly among human resource management practitioners, a view that important inter-generational differences exist among workers and that these differences provide challenges to managers in effectively managing their workforce.

(Cennamo and Gardner, 2008; Dries et al., 2008; Macky et al., 2008; Twenge and Campbell, 2008; Posthuma and Campion, 2009; Deal et al., 2010; Hoff, 2010; Twenge et al., 2010).

Current research that discusses strategies for utilizing the strengths, talents, and creativity of the intergenerational diversity in the workplace is minimal. Twenge et al., (2010) argued that while most past research on generational differences has focused on comparing Boomers and Generation X. While such views have been challenged, academic research is scarce into intergenerational differences. (Benson \& Brown,2010). Boundaries between generations are both fuzzy and questionable (e.g. Kanfer and Ackerman, 2004; Hedge et al., 2006; Zacher et al., 2010).

\section{Defining Generations :}

A Generation is a group of people who, based on age, share not only a chronological location in history but also the experiences that accompany it. These common experiences, in turn, prompt the formation of shared beliefs and behaviors (Steelcase Inc., 2011)

A generational group, often referred to as a cohort, includes those individuals who share historical and/or social life experiences (Kupperschmidt, 2000; Smola\& Sutton, 2002; Weston, 2006).

Generational theory is based on the belief that the powerful influence of historical events and conditions that each person experiences as they mature into adults, creates a unique set of shared beliefs, attitudes, and values (Giancolo, 2006). 
A generational group would be an example of social identity theory in action, where a group of people looks toward their generational group for their social identity. (Patalano, 2008).

\section{Defining Generational Cohorts :}

This core theoretical premise underlying generational differences is not without criticism.Despite the wide variety of labels, shifts in attitudes and values can be observed with each youth generation, (Wolburg\&Pokrywczynski, 2001).

As a construct, a generational cohort refers to an "identifiable group that shares birth years, age location, and significant life events at critical developmental stages" (Kupperschmidt, 20000.There are problems in deciding the exact point at which to separate the various generations (Macky et al.,2008). They reflect the values emphasized during these particular events of periods of time (Twenge et al., 2010; Murray et al, 2011). There is also a debate over the fitting labels given to each generational group and the birth years that comprise each group. Theorists and practitioners have defined generational cohorts as individuals born around the same time who share distinctive social or historical life events during critical developmental periods.

\section{Focusing on Generation X and Generation Y :}

Tulgan (2004) indicated that by 2006, for every two oldest workers exiting the workforce, one new worker will enter. Tulgan (2004) projected that Generations X and Y workers will transform the workplace and liberate it from the traditional career path, old-fashioned supervisory tactics, outdated standards, and ineffective work designs. While that is true, India's demographics are creating some unique challenges.Unlike other periods of United States (U.S.) history, the alignment of resources, power, and position within the organization is no longer hierarchical based, with the older, more senior employees controlling the hierarchy.(Zemke et al., 2000). Only in this way, the inevitable rattle amongst the generations become more controllable, lessening the possible misunderstandings, miscommunications, and mixed signals among employees of different generations (Smola\& Sutton, 2002). With the retirement of some of the earlier generations, Gen X-ers are and will be the veteran employees and managers as Gen Y continues to enter the workforce (Smola\& Sutton, 2002). Currently, more than half of India's population is less than 25 years of age.According to Clare (2009), more changes will occur in the workplace in the next 20 years. These two generations are the ones who will be working closely together for at least the next 20 years.Furthermore, although Gen Y members are already in the workforce, they have not become a part of critical mass. The generational shift is playing a major role in shaping the future of the workplace. By 2020, the average Indian will be only 29 years of age compared with 37 in China and the U.S., 45 in Western Europe, and 48 in Japan. 
As per an article published by Wharton University in 2014, organizations across the world have always had to manage a multigenerational workforce. This creates new challenges as each of these generations try to come to an understanding of the rules of engagement in organizations today.As a result, managers are likely to be required to deal with the generational differences that appear to exist among employees and understand the unique needs of Gen Y (Smola\& Sutton, 2002; Sujansky, 2004).

\section{Defining Generation $\mathrm{X}$ and Generation $\mathrm{Y}$ :}

\section{Generation X:}

Where their parents lived to work, Generation X works to live. (Notter,2002), Vejar,2008). Latch-key kids, often the children of divorced parents, change and work-life balance is more the rule for Generation X.(Kane,2010). This shaped Generation Xers' approach to workplace loyalty and backed their risk-taking spirit. The change includes being tolerant of alternate lifestyles and being op achieve tasks on their virtues. (Kane, 2010).Unlike their parents who dared leaders with a motive to replace them, Generation Xers tend to overlook leaders. Since children of this generation have stayed alone, they are comfortable making their own decisions. (Cole et al., 2002).Generation X or Xers, in terms of workplace attitudes, it is known as the first generation to enter the workforce after corporate downsizing. Gen Xers tend to focus on outcomes rather than the process (Dols et al., 2010). The same virtue is preferred by them at the workplace as well wherein they prefer to take instructions for the project and complete the task on their own. They are not excessivelydevoted to their employers (Bova\&Kroth, 2001; Karp et al, 2002) and are open to switching their employers.

\section{Generation Y:}

The Millennials are unlike any other youth generation in living memory by being more numerous, more affluent, more educated, and more ethnically diverse.(Kane,2010), (Howe \& Strauss, 2000). Unlike the latch-key kids of Gen X, Gen Y is described as the "center of their parent's lives" (Hirschman, 2006) and the "most wanted" generation of the past century. Generation Y, concerned with careers that improved the world, want their contributions recognized and accredited (Kyles, 2009). Consequently, parent/child relationships intensified, with the majority of Gen Y characterizing their relationship with their parents as "very close" (Greenberg Quinlan Rosner Research/Polimetrix, 2005; Hira, 2007; Jayson, 2006; Weiss, 2003). These generations have such large expectations, considering that their technological sophistication allows Gen Y members to consider the world a smaller, diverse, highly-networked environment, with pretty much everything at the tip of their fingers (Patterson, 2007, Notter,2002,Vejar,2008). Tolbzie (2008), calls them the "Trophy Generation" or "Trophy Kids" 
based on the emerging trend in sports and competition to reward everyone for participation, rather than for winning" (p.12). They tend to be more interested in the work than the employer. Because of this experience, they reject the in-house competition and politics. Generation Y or Nexters or Millenials have grown along with the internet. They are a diverse generation with an open mind and acceptance for differences (Gravett\& Throckmorton, 2007).Gen Yers also flourish on flexibility compared to preceding generations.(Martin \&Tulgan, 2001). Although $60 \%$ of the Gen Y cohort was born both working parents, compared to the Gen X cohort, Gen Y members not only had the support from their parents, but also had infrastructures such as childcare, preschool, and after school programs (Weston, 2006). This has made their perspective more global, connected, and around the clock. Generation Xers are no strangers to technology, but Millennials have grown on PCs, email, and the internet.

\section{Factors Affecting the Generations :}

This 'generational habitus', serves to 'generate and structure individual practices and which arise and are defined by the forces operating in a particular generational field' (Gilleard 2004). This argument is similar to that of developmental psychologists who "view youth as a kind of "critical period" for learning about society' (Schuman and Scott 1989).

The work-related values, beliefs, needs, aspirations, and expectations of the two-generational cohorts are different. If this is the case then, in a work setting, many of the workers' values and attitudes towards work may be quite different from earlier generations of workers. People from the same generational cohort havecertainly shared "generational characteristics", which affect their outlook on life and work (Kupperschmidt, 2000; Glass, 2007; Dries et al., 2008). Burke's study for the Society for Human Resource Management found that in organizations with 500 or more employees, $58 \%$ of human resource management (HRM) professionals reported conflict between younger and older workers, largely due to their different perceptions of work ethics and work-life balance requirements. New York Times writer Virginia Heffernan in 2011, suggested that "each generation tends to accentuate its own distinctive experiences, not thinking that others before or others who follow may have similar experiences, but in different social contexts" (Lewis \& Walker, 2010). Motivating each group to work together requires an abandonment of a one-style-fits-all approach (Hymowitz, 2007). Kupperschmidt, 2000; Domeyer, 2006; Durkin, 2007a; Glass, 2007; Cates, 2010; Venus, 2011; Pita, 2012). A 2004 survey by SHRM (SHRM Survey Program, 2004) found that 40\% of HR professionals observed conflict among employees as a result of generational differences. Misunderstandings between different generational employees is growing and problematic (Zemke et al, 1999), as there are different work values between generations (Gursoy et al, 2008; Lancaster and Stillman, 2002).Leaders in various organizational settings should understand these generational differences 
to be more effective in leading a multigenerational labor force (Asfour,Lettau,2014), (Mannheim and McMullin et al. ,1952)

Such an approach allows individuals from various "levels" of the organization to become involved as equal members of a team, and as a result, it attempts to neutralize the hierarchical structure and permit individuals of different age groups to interact as peers (Weston, 2006). Employees from the same generation are likely to share the same work values, and these values vary from generation to generation (Gursoy et al., 2008) including views towards authority (Smola and Sutton, 2002), leadership (Sessa et al., 2007), work-related goals (Crawford \& Hubbard, 2008), soft knowledge situations (Bush et al., 2008) and work values themselves (Gursoy et al., 2008; Chen \& Choi, 2008). The similarities and differences between generations may be attributed to the social and historical events, which occurred during the coming of age experiences during the formative years between youth and adulthood (Howe \& Strauss, 1991). It is said that these events define a generation by shaping attitudes, traits, and values.(Patalano,2008) The idea that generations have different expectations and attitudes about work, in terms of leadership, work ethic, and values, has been substantiated via many empirical studies (Dulin, 2005; Murphy, 2000; Pekala, 2001; Pierson, 2001; Smola\& Sutton, 2002). (2007) suggest that generational differences in people's attitudes and values are the results of significant economic, political, and social events that they experience during their formative years of childhood. In traditional bureaucratic structures, the interactions between people from different generations followed hierarchical lines (Weston, 2006). Although this structure is still common in various organizations, the introduction of total quality management and continuous quality improvement has led many organizations to implement a more team-based approach (Weston, 2006). (Chan, 2005).

. It is believed that their characteristics affect their worldview, relationships, work ethic and behaviour, motivators, inclination towards teamwork, communication preferences, perception of organizational hierarchy, how they manage change, etc. (Reisenwitz and Iyer,2005).

As per the SHRM survey,2004, HR professionals observing this singularity, 28\% agreed that conflict among generations increased over the last five years and will rise to $33 \%$. In contrast, many feel that although Generation X and Generation Y are similar in their practicalviewpoint on life, there are differences in work preferences. This leads to a definition of a generation as 'a cohort of persons passing through time that come to share a common habitus, hexis and culture, a function of which is to provide them with a collective memory that serves to integrate the cohort over a finite period (Eyerman and Turner 1998, p. 2-3). 114). 93). As per an article by Julie Cogin, published in the International Journal of Human Resource Management, 2011, Workplace is becoming increasingly age-diverse and the likelihood that an older employee will report to a younger manager is increasing.

According to Tolbize, 2008, Twenge, 2010, Notter J., 2002, Suk \& Chan, 2005, Patterson, 2007, Reisenweitz\& Iyer,2009, Campbell, Hofman\& Lance, 2008, Leiber,2010, Muthu,2011 and 
Fernandes, 2011, Gen X and Gen Y employees can differ on the following work-related variables:

- Work Engagement

- Career Development

- Teamwork

- Volunteerism

- Brand loyalty

- Work aversion

- Risk Aversion

- Work-Life Balance

- Personal Beliefs

\section{Conclusion :}

Generation $\mathrm{X}$ and Generation $\mathrm{Y}$ both are found to be ambitious and like to be autonomous. Both lack interpersonal skills but value work-life balance. Both generations are technologically sound, though Generation X has learned it and Generation $\mathrm{Y}$ has grown with it.

Both the generations like a good working environment at the workplace and prefer to work in a flexible structure and do not intend to stick for a particular employer for a longer period without reaping any personal benefit.

Keeping in view these facts and literature the mentioned factors will play a critical role in understanding the difference between both generations and harmonizing their relationship for the betterment of the organization.

\section{Limitations and future scope of the study :}

This study recognizes its limitation of being based on literature only. A primary study can be conducted based on a questionnaire for recording the preferences of both generations and can be compared over a period of time under a longitudinal study. 


\section{References :}

1. Aldisent, L. (2002). Valuing People! How Human Capital Can Be Your Strongest Asset. Chicago, IL: Dearborn Trade Publishing. Patterson, C. (2007), "The impact of generational diversity in the workplace", Diversity Factor, 15(3), pp. 17-22.

2. Arsenault P., (2004), "Validating generational differences: A legitimate diversity and leadership issue", Leadership \& Organization Development Journal, Vol. 25 Issue: 2, pp.124-141, https://doi.org/10.1108/01437730410521813

3. Benson J. \& Brown M. (2011), "Generations at work: are there differences and do they matter?", The International Journal of Human Resource Management, 22:9, 1843-1865 DOI: $10.1080 / 09585192.2011 .573966$

4. Beutell, N. J., \& Wittig-Berman, U. 2008. Work-family conflict and work-family synergy for generation X, baby boomers, and matures. Journal of Managerial Psychology, 23: 507-523.

5. Bova, B. \&Kroth, M. (1999). Closing the gap: the mentoring of generation X. Journal of Adult Education, (27)1: 7-17.

6. Cates, S.V. (2010), "Generational management in corporate America: the differences and challenges in management of four generations of working adults", Chinese Business Review, Vol. 9 No. 8, pp. 46-54

7. Cennamo, L. and Gardner, D. (2008), "Generational differences in work values, outcomes, and person-organisation fit", Journal of Managerial Psychology, Vol. 29 No. 8, pp. 891-906

8. Clausing S., Kurtz D., Prendeville J. and Walt J.(2003), "Generational Diversitv-The Nexters",Clausing - Kurtz - Prendeville - Walt, VOL 78, NO 3

9. Cogin J. (2011), "Are Generational differences in workplace fact or fiction? Multi country evidence and implications", The International Journal of Human Resource Management, Vol 23. Iss.1

10. De Lange, A.H., Taris, T.W., Jansen, P. , Kompier, M.A.J., Houtman, I.L.D. and Bongers, P.M.(2010), "On the relationships among work characteristics and learning-related behavior: does age matter?", Journal of Organizational Behavior, 31(7), pp. $925-950$

11. Deal, J.J., Altman, D.G. and Rogelberg, S.G. (2010), "Millennialsat work: what we know and what we need to do (if anything)", Journal of Business \& Psychology, 25(2), pp. 191-199

12. Dries, N. , Pepermans, R. and de Kerpel, E. (2008), “Exploring four generations' beliefs about career - is 'satisfied' the new 'successful'", Journal of Managerial Psychology, 23(8), pp. 907-928

13. Eyerman, R. and Turner, B.S. (1998), "Outline of a theoryof generations", European Journal of Social Theory, 1(1), pp. 91-106. 
14. Gursoy, D. Maier, A. \& Chi, C. (2008). Generational Differences: An examination of work values and generational gaps in the hospitality workforce. International Journal of Hospitality Management, (27)2008: 448-458.

15. Kaifi. B, Nafei W., Khanfar N and Kaifi M.(2012), "A Multi-Generational Workforce: Managing and Understanding Millennials", International Journal of Business and Management; Vol. 7, No. 24,doi:10.5539/ijbm.v7n24p88

16. Khosla S. (2015), "Emerging Organisational Trends in Training \& Development in India”, Journal of Business Management \& Social Sciences Research (JBM\&SSR), Volume 4, No.1

17. Lawler, E.E. (1969), “Job design and employee motivation”, Personnel Psychology, Vol. 22 No. 4, pp. 426-434.

18. Lester S., Standifer R., Schultz N. and Windsor J. (2012), "Actual Versus Perceived Generational Differences at Work: An Empirical Examination", Journal of Leadership \& Organizational Studies 19(3) 341 -354,DOI: 10.1177/1548051812442747

19. Louglin, C, \&Barling, J. (2001) "Young workers' work values, attitudes, and behaviors" Journal of Occupational and Organizational Psychology, 74(A), 543-559.

20. Macky K., Gardner D. and Forsyth S. (2008), "Generational differences at work: introduction and overview", Journal of Managerial Psychology, Vol. 23 Issue: 8, pp.857861, https://doi.org/10.1108/02683940810904358

21. McMullin, J., Comeau, T., and Jovic, W. (2007), 'Generational Affinities and Discourses of Difference: A Case Study of Highly Skilled Information Technology Workers,' British Journal of Sociology, 58, 2, 297-316.

22. Montana P. and Petit F. (2008), "Motivating Generation X And Y On The Job And Preparing Z", Global Journal Of Business Research, Volume 2, Number 2,2008

23. Paul M. Arsenault, (2004) "Validating generational differences: A legitimate diversity and leadership issue", Leadership \& Organization Development Journal, Vol. 25 Issue: 2, pp.124-141, https://doi.org/10.1108/01437730410521813

24. Pita, K. (2012), "Five generations in the workplace", Fairfield County Business Journal, Vol. 48 No. 8

25. Posthuma, R.A. and Campion, M.A. (2009), "Age stereotypes in the workplace: common stereotypes, moderators, and future research directions", Journal of Management, Vol. 35 No. 1, pp. 158-188

26. Reisenwitz T. and Iyer R. (2009), "Differences In Generation X And Generation Y: ImplicationsFor The Organization And Marketers", The Marketing Management Journal Volume 19, Issue 2, Pages 91-103

27. Rood A. (2010), "Understanding Generational Diversity in the Workplace: What Resorts Can and are Doing","Journal of Tourism Insights: Vol. 1: Iss. 1, Article 10.https://doi.org/10.9707/2328-0824.1009.

Available at:http://scholarworks.gvsu.edu/jti/vol1/iss1/10 
28. Sessa, V., Kabacoff, R., Deal, J. \& Brown, H. (2007). Generational Differences in leader values and leadershipbehaviors. The Pyschologist-Manager Journal, (10)1: 47-74.

29. Stevens R. (2010), "Managing Human Capital: How to Use Knowledge Management to Transfer Knowledge in Today's Multi-Generational Workforce", International Business Research Vol. 3, No. 3.

30. Stevens R. (2010), "Managing Human Capital: How to Use Knowledge Management to Transfer Knowledge in Today's Multi-Generational Workforce", International Business Research Vol. 3, No.3;DOI: 10.5539/ibr.v3n3p77

31. Sturman, M.C. (2003), "Searching for the inverted U-shaped relationship between time and performance: meta-analyses of the experience/performance, tenure/performance, and age/performance relationships", Journal of Management,29(5), pp. 609-640

32. Twenge J., Campbell S., Hoffman B.and Lance C., (2010), "Generational Differences in Work Values: Leisure and Extrinsic Values Increasing, Social and Intrinsic Values Decreasing”, Journal of Management Vol. 36 No. 5, September 2010 1117-1142 DOI: $10.1177 / 0149206309352246$

33. Weston, M.J. (2006). Integrating generational perspectives in nursing. Online Journal of Issues in Nursing, J ,Vol. 1(2), 12-22.

34. Wolburg, J. M., \&Pokrywczynski, J. (2001). A psychographic analysis of Generation Y college students. Journal of Advertising Research, Vol. 41(5), pp. 33-53.

35. Zacher, H. , Heusner, S. , Schmitz, M. , Zwierzanska, M.M. and Frese, M. (2010), "Focus on opportunities as a mediator of the relationships between age, job complexity, and work performance", Journal of Vocational Behavior, 76(3), pp. 374-386 